\title{
THE ELASTIC TISSUE OF THE TESTIS IN NORMAL AND IN PATHOLOGICAL CONDITIONS.
}

\author{
By J. W. Roв, M.D., M.A., B.C.(Cantab.). \\ From the Pathological Laboratory, University of Cambridge.
}

(Plates XXXI. and XXXII.)

THE publication of Weigert's article (1898) marks an epoch in the study of elastic tissue. Before this, orcein had been used to stain elastic fibres, and some workers still prefer it, though Weigert's stain is becoming more and more popular.

The elastic tissue of the vascular system absorbed most of the attention of the early observers, but during recent years a considerable amount of literature has been published dealing with the elastic tissue of the lung. In addition, Hohenemser (1895) and Mironescu (1903) have done work on the elastic tissue of the liver; Meissner (1896) and Katzurada (1902) on that of the skin; Iwanoff (1902), Pick (1900), Dittel (1896), and Woltke (1900) on that of the uterus; White (1900), Williams (1900), and Hamilton (1900-1901) on that of tumours, not to mention the studies of Melnikow-Raswedenkow (1899), Wechsberg (1901), Watanabe (1902), Eijkman (1904), Jores (1898 and 1900), Fischer (1904), and many others. Federmann (1901) has written on the behaviour of the elastic tissue of the testis in syphilis and tuberculosis.

The increasing popularity of Weigert's stain ${ }^{l}$ is partly due to the fact that it is easier to use than orcein, but mainly to the fact that by using lithiumcarmine as a counter-stain a strong and beautiful contrast is obtained between the elastic fibres and the other tissues, which cannot be obtained if orcein is used. A further advantage of the use of Weigert's stain is that extremely fine and delicate elastic fibrils can be seen comparatively easily if stained by this method, whilst if they are stained with orcein it is often a difficult matter to distinguish them clearly.

Most of the fresh specimens I obtrined were hardened in formalin, but I think equally good, if not better, results might be obtained by the use of alcohol or Miiller's fluid. It is often necessary to embed friable specimens in paraffin, and this is usually the best course to adopt with specimens which have been hardened or preserved in spirit ; but paraffin sections do not stain so quickly by this method as frozen sections.

After hardening in formalin fresh specinens were embedded in gum, and

1 Weigert's stain works better if it is allowed to stand in a stoppered bottle for about a week before being used. Another advantage obtained by using this stain is that good results may be obtained with sections which are not very thin, $4 \mu$ or even $6 \mu$ is quite a workable thickness. When dealing with an organ like the testis this is an important point, owing to the difficulty of spreading out a very thin section of this organ without tearing it. When a soft, friable tumour is being handled this difficulty becomes greater still. 
sections cut with an ordinary ether-freezing microtome. The sections stain quickly in lithium-carmine, and from one to three minutes is all they require in this stain. After staining in lithium-carmine they should be left in a 1 per cent. solution of hydrochloric acid in 95 per cent. alcohol for at least twenty-four hours. They are usually sufficiently stained by Weigert's stain in an hour, or an hour and a half. Paraffin sections take an hour or an hour and a half to stain in lithium-carmine, and two or three hours in Weigert's stain. Eosin or van Gieson's stain, with or without previous staining in hæmatoxylin, may be used as a counter-stain instead of lithium-carminc.

My object throughout the work has been to try and throw some light on the following points:testis.

1. The condition of the elastic tissue normally present in the

2. The condition of the elastic tissue of the vessels.

3. The destruction of elastic tissue.

4. The formation of new elastic tissue.

The following is a brief summary of the work of other observers so far as it bears upon these points:-

1. Elastic fibres as compared with other tissues are relatively very resistant to destructive processes.

2. Acute septic processes cause the most rapid destruction of elastic tissue.

3. Next to septic processes, tuberculosis causes the most rapid destruction of elastic tissue.

4. In malignant disease the elastic fibres in the normal tissues are destroyed, but sarcoma effects this more rapidly than carcinoma.

5. In tertiary syphilis there is comparatively very little destruction of elastic tissue.

6. In arterio-sclerosis and in syphilis the internal elastic lamina of the arteries is broken up and new elastic fibres are formed.

7. In scars, chronic inflammatory processes and tumours, especially soft malignant growths, there may be new formation of elastic tissue.

\section{Normal Testis.}

The amount of elastic tissue in the testis is surprising. In every part of the organ elastic fibres are present in large numbers. Taking the different parts separately, these fibres are distributed as follows :-

The tunica albuginea and tunica vaginalis consist mainly of dense fibrous tissue, but scattered amongst the white fibres are numerous, separate, elastic fibres. These elastic fibres are neither so fine nor so coarse as are those found in other parts of the testis. They communicate with one another by fine branches, and are connected in a similar manner with the elastic fibres in the body of the testis and in the walls of the vessels. The tunica vaginalis is, on the whole, richer in these elastic fibres than is the tunica albuginea.

The body of the testis contains relatively little interstitial tissue, 
and sometimes the walls of the seminal tubules are almost in contact with one another, but as a rule they are separated by a small amount of areolar tissue. In this intertubular, interstitial tissue some fine elastic fibres are irregularly scattered. For the most part these elastic fibres are single, or only two or three together, but sometimes, especially near the vessels, they are collected into little bands or sheaves. They communicate with one another by branches, and also with the elastic fibres in the tunica albuginea, in the walls of the seminal tubules, and in the walls of the vessels.

Each seminal tubule is surrounded by a complete sheath of thick elastic fibres, closely interwoven with one another into a compact network. A section of the testis, therefore, stained with lithiumcarmine and Weigert's stain presents a very striking appearance. The elastic sheath, stained a brilliant violet, surrounds the epithelium of the tubules, which is stained a vivid red, so that the structure of the organ is demonstrated very clearly and diagrammatically.

The elastic sheath of the seminal tubules is of considerable thickness, and often six or more elastic fibres interwoven together may be seen in a section at right angles to the long axis of the tubules. These fibres, in addition to being interwoven, are united with one another by branches. Between them, filling up the small meshes of the compact network they form, is a minute amount of very delicate areolar tissue. There is also a very thin layer of very delicate areolar tissue between the epithelium of the seminal tubules and their elastic sheath.

The arrangement of the elastic tissue in the epididymis is similar to that in the body of the testis. Each tubule has a complete sheath of closely-interwoven elastic fibres, and the intertubular areolar tissue also contains a few scattered elastic fibres. The fibres composing the sheath of the tubules are rather finer than those in the sheath of the seminal tubules of the testis proper, and they are rather less closely interwoven. The amount of intertubular areolar tissue is also greater in the epididymis than in the testis proper, and the number of elastic fibres dispersed throughout it is larger. With these exceptions the description of the elastic tissue of the body of the testis applies to that of the epididymis.

There is a definite, thick layer of elastic tissue in the wall of the vas deferens between the epithelium and the muscular coat. This layer, which is composed of interwoven elastic fibres, at first sight resembles the internal elastic lamina of an artery. It is, however, thicker than the internal lamina. The interstices of the network of which it consists are filled with very delicate areolar tissue, and it is separated from the epithelium and from the muscular coat by a very thin layer of very delicate areolar tissue. There are numerous elastic fibres scattered here and there between the bundles of muscle fibres in the muscular coat.

The elastic tissue of the vessels of the testis has a similar arrange- 
ment to that of the vessels in other parts of the body. Between the endothelium and the muscular coat of the wall of the arteries is the internal elastic lamina, a well-marked layer of closely interwoven, fine, branching elastic fibres, forming a dense network, and not, as the common nomenclature implies, a sheet or fenestrated membrane. Fine elastic fibres lie dispersed throughout the tunica media between the muscle fibres. Outside the muscular coat is the external elastic lamina, which is not so thick, but of a similar constitution to the internal lamina. The tunica adventitia of the arteries contains several scattered elastic fibres. In the veins there is much less elastic tissue than in the arteries. The tunica media contains no elastic fibres, and there is no external elastic lamina. The internal elastic lamina is thinner in the veins than in the arteries.

\section{Tuberculous Disease of the Testis.}

Wechsberg (1901) observed destruction of elastic fibres in from six to twenty-four hours after intra-venous injection of tubercle bacilli. Watanabe (1902) records destruction of elastic tissue in the lung within twenty-four hours of experimental inhalation of tubercle bacilli. Sawada (1902), Miller (1905), Melnikow - Raswedenkow (1899), Herxheimer (1903), Rona (1900), Federmann (1901), and several others describe destruction of elastic tibres in tuberculosis.

If a section of a testis which is the seat of an early, acute, tuberculous lesion be examined after staining with Weigert's stain, the amount of destruction of elastic tissue is seen to be very large. Often suall, obviously young, submiliary tubercles may be seen, all the elastic tissue in contact with which is either in progress of destruction or has been destroyed. In such cases the destruction of the elastic fibres seems to have taken place very quickly.

When the tuberculous tissue is invading the elastic sheath of the seminal tubules, but especially when the tubules are becoming involved in a large tuberculous nodule, a great infiltration of small round cells may be seen separating the elastic fibres from one another, and forcing them apart. The small round cells seem to make their way into the sheath of the tubules by passing through the meshes in the elastic network. Sometimes they advance between the elastic fibres round the circumference of the tubule, and peel off some of the elastic fibres like one of the coats of an onion. At other times the small round cells pierce right through the elastic sheath, and make a breach in it without separating any of the elastic fibres except those which lie close to the sides of the breach-that is to say, without advancing more than a short distance round the circumference of the tubule. In this case the elastic fibres on each side of the breach are spread out in a fanshaped manner.

The elastic tissue is also either destroyed, or in process of destruc- 
tion, at the extreme margin of tuberculous nodules, even where the tuberculous granulation tissue has not yet reached, or, at all events, where the small round cells are very scanty, so that there appcars to be a small area clear of elastic tissue round each tubercle.

As might naturally be expected, the process by which the seminal tubules are invaded is best seen in the earliest stages of the disease, as is also the destruction of the elastic fibres; and it is in the earliest stages only that anything satisfactory can be made out as to where the tuberculous lesions start and how they spread.

The method by which the elastic tissue is destroyed will be discussed later.

Not only are the elastic fibres separated from one another; they are also broken up into short pieces. The fragments become thinner than the normal fibres, and frequently their ends taper away to long fine points. They stain, however, quite clearly right up to the end.

The elastic tissue is only destroyed in the vicinity of tuberculous foci. Tubules may be seen, one side of which is undergoing destruction by the disease, the epithelium being reduced to a mass of catarrhal débris, and the elastic fibres being broken up and destroyed, whilst the elastic sheath and the epithelium at the opposite side of the tubule are unaffected.

Very often in old areas of disease no trace of elastic tissue remains, but Federmann (1901) calls attention to the fact that when caseation supervenes the destruction of elastic tissue ceases. In caseous areas, therefore, one may see indications of former seminal tubules. These consist of a rough outline of the tubules marked out by the remains of the partially-destroyed elastic sheath, and embedded in the caseous mass. How much of the elastic sheath remains depends upon when caseation supervened. The earlier caseation began the more elastic tissue will be preserved, and the longer the tuberculous process went on before caseation began the less elastic tissue will there be in the section.

In cases where suppuration has occurred the elastic fibres have been entirely destroyed in the affected area.

Sometimes seminal tubules may be seen which are full of small round cells, epithelioid cells, and débris of epithelial cells inside, whilst their elastic sheath is unbroken, and the intertubular tissue outside them is unaffected. In none of these cases are the elastic fibres of the sheath of the tubule pressed together as though the tubules were being distended by their contents. The tuberculous process seems to have invaded these tubules at some other point in their coursè, and then to have passed along inside them. This view is supported by three facts. First, that an exactly similar condition may be seen in the epididymis, where the disease starts in the interstitial tissue. Secondly, that it would be the easiest course for the disease to take when once it has invaded a tubule. And thirdly, that tubules may sometimes be 
seen in which the epithelium is not destroyed, though the interior is full of tuberculous tissue.

On the other hand, seminal tubules occur which are entirely encompassed by tuberculous tissue, and though the elastic sheath shows signs of being attacked, yet there is no breach in it, and the epithelium remains intact.

Other observers have recorded that elastic fibres are more resistant than most other tissues to destructive processes, and the conditions just recorded are evidence of this. Further support is given to this view by a condition which may occasionally be seen in advanced stages of the disease. A few small broken pieces of elastic tissue, arranged roughly in the form of an incomplete circle, and embedded in tuberculous tissue which has not become caseous, mark the position of a former seminal tubule, all the epithelium of which has disappeared.

Most of the young tuberculous foci lie near a small vessel. This, of course, cannot be seen in old cases, where the submiliary tubercles have grown and coalesced into large nodules.

Tuberculosis of the vas deferens is often both well marked and of a typical character, as well as presenting features of interest. Very pretty giant-cell systems are often present. The tubercle bacilli passing down the vas from the epididymis set up a catarrh of the epithelial cells, which sometimes proliferate so much as almost to block the lumen of the duct. The giant cells occur in this mass of epithelium, and are at first confined to it. The elastic layer in the wall of the vas resists the spread of the disease, and only in the later stages shows signs of giving way and allowing the muscular coat to be invaded. When the elastic layer does succumb to the attacks of the tubercle bacilli it does so in the same way as the elastic sheath of the seminal tubules. Having made a breach in the elastic layer, the small round cells pour through the opening and spread up and down the vas in the muscular coat, distorting the outline of the vas and destroying the muscle fibres.

The vessels near the diseased areas in tuberculosis of the testis are markedly affected. There is great proliferation of the endothelium of the arteries, so that the tunica intima becomes a great many times its normal thickness. The internal elastic lamina is greatly thickened, contorted, and broken up. The ends of the broken elastic fibres, in contrast to the broken fibres of the elastic sheath of the seminal tubules, do not taper at the ends, but are curled round and swollen into the shape of a club. New elastic fibres are formed on both sides of the elastica, and also in the tunica media. These new fibres are thinner than the others, but they are sometimes inassed together into clumps which lie close to the internal elastic lamina, and give to it the distorted appearance mentioned above. The muscular tibres in the tunica media are degenerated and atrophied, and the white fibrous tissue amongst them is increased in quantity. 


\section{The Starting-Point of Tuberculous Disease of the Testis.}

There is a good deal of difference of opinion on this question. Federmann (1901) believes that in the vast majority of cases the disease originates in the epithelium of the seminal tubules, though he admits that it may sometimes begin in the extra-tubular interstitial tissue. Baumgarten (1900) holds similar views. He conducted some experiments to elucidate the point, but was unable to cause tuberculosis of the testis in animals by intra-ocular, intra-venous, intra-peritoneal, subcutaneous or intra-arterial injections of cultures of virulent tubercle bacilli. Nor did the testis become affected secondarily to artificial tuberculosis of the bladder or prostate. He succeeded in producing the disease, however, by injecting virulent tubercle bacilli direct into the body of the testis.

Neither these experiments nor the attempts of Kraemer (1900) to cause tuberculosis of the testis by forcing cultures of virulent bacilli down the vas deferens are very conclusive. Direct injection of tubercle bacilli into the body of the testis might be useful for observing the effect of the disease on the elastic fibres, but it can hardly have much weight in determining the starting-point of the disease.

Virchow (1863-67) states clearly and emphatically his belief that tuberculosis of the testis starts in the interstitial tissue and not in the epithelium of the seminal tubules.

According to J. Hutchinson, jun. (1895), Malassez admitted that the most striking lesions occurred outside the seminal tubules, and some of his illustrations show degenerating tubules enveloped in tuberculous tissue. Hutchinson also says that typical tubercles and giant cells may be seen outside the seminal tubules, and that the process probably starts in the interstitial tissue near the vessels in acute miliary tuberculosis.

It is not of much avail to give lists of names on one side or the other, so I will only mention that Baumgarten quotes Orth and Langhans amongst others in support of his view, whilst Erichsen and Bowlby agree with Virchow.

Except in rare cases, tuberculous disease of the testis begins in the epididymis, and as this usually occurs when there is no other focus of disease in the genito-urinary tract it is reasonable to believe that the tubercle bacilli reach the testis in the blood. This appears to be the more likely when it is remembered that tuberculosis of the epididymis is often consequent upon some other focus of disease, latent or patent, in the lungs, lymphatic glands, or some other part of the body.

The important point, then, is to determine how the body of the testis becomes infected from the epididymis. Now, there are four situations in the testis in which the disease may start, and these may 
be divided into two groups according to whether the tubercle bacilli reach the starting-point from the epididymis by way of the seminal canals or by way of the vessels and lymphatics.

$A$. Infection by way of the seminal canals.

1. Process starts in the epithelium of the seminal tubules.

$B$. Infection by way of the vessels and lymphatics.

2. Process starts in the intertubular interstitial tissue.

3. Process starts in the minute amount of delicate areolar tissue between the interwoven elastic fibres of the sheath of the seminal tubules.

4. Process starts in the minute layer of delicate areolar tissue between the epithelium and the elastic sheath of the seminal tubules.

None of my sections showed the tuberculous process starting in the epithelium of the seminal tubules, and reasons have already been given why this was not the case in some sections where a superficial examination at first supported this view. Attention has also been drawn to the fact that submiliary tubercles usually occur near small vessels.

Now, there is one site in which the tuberculous process undoubtedly starts in the epitheliun, and that is the vas deferens. The disease here is secondary to tuberculous epididymitis, and the tubercle bacilli conveyed along the vas in the semen set up a catarrhal process in the epithelium of the vas. If then the disease in the body of the testis starts in the epithelium of the seminal tubules, there ought to be a close resemblance between the early stages of the disease in both places. But there is not. Large numbers of typical giant-cell systems embedded in the proliferating epithelium may be seen in the vas deferens, whilst, at the same time, the elastic layer in the wall of the vas remains unbroken, but not in the seminal tubules of the testis proper. Proliferation of the epithelium of the seminal tubules often occurs, and giant-cell systems may be seen inside the seminal tubules. But in such cases the elastic sheath of the tubules has been broken through by a tubercle lying in the extra-tubular interstitial tissue (Plate XXXII. Figs. 8 and 9), or it has been considerably damaged by a tubercle starting in the meshes of the network of elastic fibres, or in the fine layer of delicate areolar tissue between the epithelium and the elastic sheath, or the tubule has been invaded at some other point in its course. I have seen no evidence of a tubercle slarting in the epithelium of the seminal tubules.

Again, when a tubule is becoming involved in a large tuberculous nodule the destruction of the elastic sheath takes place in the same manner as when a single submiliary tubercle is attacking a tubule. In the former case the tubule is obviously invaded from outside, and if, in the latter case, the disease attacked the elastic sheath from inside, 
there ought to be some difference in the process in the two cases; but there is none.

Further, the process starts in the interstitial tissue round the vessels in the epididymis, and there is no difference between the process of destruction of the elastic tissue of the tubules here and in the testis proper, as might be expected if the process started in the epithelium of the seminal tubules in the testis proper.

Those seminal tubules which have been invaded by the disease at a point in their course from which the disease has advanced along inside the tubule are not seen in the earliest stages of the disease. Still, even in sections where they occur young tubercles can be seen outside the seminal tubules in the interstitial tissue.

Now, if the tuberculous process does not start in the epithelium there remain three other places where it may begin, and these three have this connection with one another, that in all of them the bacilli reach the tissues from the epididymis by way of the vessels and lymphatics.

The vessels run in the intertubular connective tissue, and typical young tubercules may frequently be seen in the early stages of the disease in the intertubular tissue, usually close to a small vessel (Plate XXXI. Figs. 1 and 2). These are best seen when the testis is only spotted with tiny tuberculous foci which have not coalesced into large nodules. There are lymphatic vessels in the areolar tissue between the elastic fibres of the sheath of the seminal tubules, so that tubercle bacilli may easily lodge in the meshes of the network these fibres form. Now, typical giant-cell systems may be seen in this situation, surrounded on all sides by elastic fibres or fragments of elastic fibres. The tubercle is separating the elastic fibres and destroying them (Plate XXXII. Figs. 7, 8, and 9). The process clearly is not that of an invasion of the elastic sheath by a tubercle starting either inside or outside the sheath, but a process originating in the elastic sheath, splitting it longitudinally and circumferentially, and forcing the elastic fibres apart. A close examination of such a condition leaves no doubt in the mind that the tubercle started in the elastic sheath of the tubule.

Again, submiliary tubercles may be seen which are separating the epithelium of the seminal tubules from the elastic sheath. The epithelium is raised from off the sheath and bulged into the lumen of the tubule, but the layer of epitbelium is not broken through though the cells are proliferating, nor is the elastic sheath broken through though its fibres are undergoing destruction. Once more it may be said that a close examination leaves no doubt in the mind that the tubercle started in the thin layer of delicate areolar tissue between the epithelium and the elastic sheath of the seminal tubule.

That the tubercle bacilli should be conveyed from the epididymis to the body of the testis by the lymphatics would fall into line with 
what is known of their distribution in other parts of the body, and it is only in this way that the origin of the conditions just described can be satisfactorily explained.

In an early case of tuberculosis of the testis there may be seen in the same section tubercles starting in all the three positions mentioned above, $B$ 2, 3, and 4. Most often the process begins in the intertubular connective tissue, more rarely between the elastic fibres of the sheath of the seminal tubules, and comparatively seldom between the epithelium and the elastic sheath.

\section{Gumma of the Testis.}

There is a general agreement amongst all pathologists that gumma of the testis is an entirely extra-tubular, interstitial disease.

The behaviour of the elastic fibres in syphilis forms a strong contrast to their behaviour in tuberculosis. Miller (1905) found the elastic tissue of the lung well preserved in a case of gumma, and the same words excellently describe the condition of this tissue in the testis.

Whereas in tuberculosis the elastic fibres are rapidly and extensively destroyed, in tertiary syphilis they are very little affected.

The chief change in gumma of the testis is a large increase in the amount of intertubular interstitial tissue (Plate XXXI. Fig. 3). The walls of the seminal tubules, instead of being almost in contact with one another, are separated by intervals not infrequently several times as wide as the diameter of the tubules. The elastic fibres of the sheath of the seminal tubules are not much changed. They stain well, and are not broken up. On the other hand, the epithelium shows definite degenerative changes. The cells are necrotic, their outline is indistinct, their nuclei difficult to make out, and their capacity for taking up a stain almost nil. The cause of this is probably that the great invasion of small round cells into the interstitial tissue interferes with the supply of nutrition to the epithelium.

In consequence of these changes a section of gumma of the testis stained with lithium-carmine and Weigert's stain presents a striking picture. The richly cellular intertubular tissue stains a vivid red, and embedded in it are the seminal tubules, the elastic sheath of which, stained a brilliant violet, surrounds an unstained mass of degenerating epithelium.

The increased interstitial tissue by pressing on the outside of the seminal tubules sometimes distorts their shape by crumpling their walls.

In advanced stages of the disease the elastic fibres are to some extent affected. They may be not so well stained as usual, or even broken up a little, and occasionally small round cells may be seen in between the fibres. But these conditions never occur to nearly the same extent that they do in tuberculosis. Possibly they are due to an 
interference with nutrition similar to that which caused the death of the epithelium only; the elastic fibres being more resistant do not succumb so quickly as the more delicate and susceptible epithelial cells.

In areas where suppuration has occurred the elastic fibres have been completely destroyed.

The vessels in the gumma are considerably affected, in much the same way and to much the same extent as in tuberculosis. There is great thickening of the tunica intima due to proliferation of the endothelium, and the internal elastic lamina is thickened, contorted, and broken. New elastic fibres are formed, not only near the internal lamina, but also in the tunica media. These changes are well described by Coplin (1904).

\section{Carcinoma of the Testis.}

The elastic tissue is destroyed in carcinoma, but neither so rapidly nor so extensively as in tuberculosis or sarcoma. In the oldest parts of the growth there is no normal elastic tissue to be seen, but near the edge of the tumour the seminal tubules are being compressed or otherwise distorted in shape. Often the neoplasm grows round the tubules so as to envelop them completely, and only later destroys the elastic sheath.

Sometimes one may see seminal tubules which are full of carcinomatous tissue inside, whilst the elastic sheath is intact. In these cases the epithelium has been entirely destroyed. The growth has either spread into these tubules by way of the lymphatics, or has invaded them at some other point in their course, and has spread along inside them.

These conditions are illustrations of the relative resistance of the elastic fibres to destructive processes which has been noticed in various pathological conditions by many observers.

Still the elastic tissue is destroyed by carcinoma, as the absence of this tissue in the older parts of the growth shows. Furthermore, the growth can be sometimes seen invading a seminal tubule through a hole which it has made in the elastic sheath. How the carcinoma destroys the elastic fibres is not clear, but one can sometimes see the cells of the growth passing through the meshes in the network of elastic fibres in the sheath of the tubules. The fibres become separated from one another by the carcinoma cells, and then broken up into shorter pieces.

I was given a specimen of a cauliflower growth of the testis which under the microscope showed the structure of a typical epithelioma, but I could not obtain any information as to whether it was a primary or a secondary growth. The elastic tissue of the seminal tubules was destroyed in a manner and to an extent very similar to that just 
described in carcinoma. The vessels showed nothing of importance either in this epithelioma or in carcinoma.

Frequently in carcinoma there is a very large amount of newly formed elastic tissue. This is especially the case when the growth is of a soft, richly cellular character, containing little white fibrous tissue in its structure, and in these neoplasms very often by far the most striking feature is the large amount of new elastic tissue. Not seldom these new elastic fibres are collected into masses (Plate XXXI. Fig. 6) which, when stained, are easily visible to the naked eye. These masses are of a very irregular shape, and are composed of a disorderly tangle of fibres. In the centre of the masses the fibres are large and coarse, and are closely interwoven, but near the margin they are farther apart and not so thick, whilst at the edge they become quite thin; they are spread out in a fan-shaped manner. All these fibres are well defined, branched, and clearly stained.

Still more delicate fibres than those which lie at the edges of these larger masses are to be found at the growing edge of the tumour (Plate XXXI. Fig. 5). They are so fine that they can only be examined properly with an oil-immersion objective. They are situated between the cells of the growth, round which they twine. In spite of their delicacy these fibres are very definite, and stain quite clearly with Weigert's stain. They surround the cells so closely sometimes that they appear to form a wall for the cells, but their branches make it impossible to mistake them for such. These fibrils often pursue a sinuous course amongst the cells of the growth, branching on their way. It is by means of these branches that they appear to enclose the cells. A fibril will give off a branch, and in the angle will be seen a cell. Another fibril pursuing a different course will also give off a branch, which by uniting with the first fibril or its branch will complete the ring round the cell. Sometimes, however, these fibrils are too short and delicate to branch, and then they form S-shaped curves round the cells, or merely curl round one cell like a letter $\mathbf{C}$.

It is difficult to describe in words the great delicacy and the peculiar arrangement of these fibrils. I have tried to give some idea of their appearance in the diagrams appended. Owing to their delicacy they are very difficult to photograph.

Whilst these fibrils only occur where the growth is richest in cells-that is to say near the edge-the large masses mentioned above lie in the older parts of the growth where the cells are scanty, and here sometimes the greater part of the stroma consists of elastic fibres.

The new elastic fibres (Plate XXXI. Fig. 4, and Plate XXXII. Fig. 10) constituted by far the most striking feature of the epithelioma mentioned above. More than a quarter of the tumour consisted of new elastic tissue, which had a similar arrangement and character to that in carcinoma. 


\section{The New Fonmation of Elastic Tissuf}

New formation of elastic fibres has been described by Miller (1905) in interstitial pneumonia, phthisis, and syphilis; by Woltke (1900) in chronic inflammation ; by Ellis (1904) in tumours treated with the X-rays ; by Baumgarten (1878) in syphilis; by Jores (1898) and Coplin (1904) in arteriosclerosis; Lewinberg (1898) says that Riehl, Guttentag, and Goldmann found newly formed elastic fibres after skin-grafting. Jores (1900) says that Wolters and Soffianti noticed new formation of elastic tissue in scleroderma, Soffianti in elephantiasis, and Kromayer in condylomata, papillomata, naevi, and molluscum fibrosum. Mr. Joseph Griffiths, of Cambridge, found an increase in the elastic fibres of the skin in a case where trophic changes followed division of the ulnar nerve. Fischer (1904) says that it is now impossible to doubt that new formation of elastic fibres does occur. Hansemann, Lubarsch, and himself have seen it in various neoplasms. Tumours of the testis and parotid are often especially rich in new elastic tissue. Hamilton (1901), in an excellent paper, describes extensive formation of new elastic fibres in tumours, especially soft, richly cellular, malignant growths. The stroma of some of these tumours was largely composed of new elastic fibres.

My sections confirm these points. It is not those tumours which are richest in white fibrous tissue which show the largest amount of new formation of elastic fibres, but the soft, richly cellular, malignant growths which contain very few white fibres in their stroma. I have described these new elastic fibres on a previous page, and I have not much to add.

In tumours of the testis, nodules of cartilage are common, and these are generally surrounded by rings of elastic tissue.

The main reasons for regarding the elastic fibres previously described as a new formation are the following: The arrangement of the fibres, their situation, and the shape and size of the masses they form are apparently very purposeless and capricious. Every size of fibre, in almost every conceivable shape and arrangement, occurred. The fibres show no definite, orderly, or useful arrangement, but are scattered here and there, or are collected in confused and indescribable masses, which are often nothing more than a wild jumble of fibres. The contrast between this state of things and the regular, orderly, and useful arrangement of the normal fibres is very great. Furthermore, no such large masses of elastic fibres as those seen in carcinoma and in sarcoma occur in the normal tissues.

It occurred to me that these masses might be composed of the elastic fibres of the broken-up sheaths of the seminal tubules. For example, in carcinoma the growth might have destroyed the epithelium but not the elastic sheath of the seminal tubules, and then the elastic fibres might have become massed together in the older parts of the growth. But the presence of the delicate young fibres amongst the cells in the growing edge of the tumour, and the obvious destruction of elastic tissue which takes place in carcinoma, and still more in sarcoma (where an equal quantity of new elastic fibres are formed), negative such a supposition, and close examination of the 
sections shows nothing to support it. The normal seminal tubules are separated from the large masses of elastic fibres by the growing edge of the tumour in which the very delicate fibrils described above occur, but in which there are no large fibres like those which compose the elastic sheath of the seminal tubules.

A further argument in favour of these elastic fibres being a new formation is that they are found in parts of the tumours which are entirely new and do not consist of normal tissues infiltrated with growth.

Again, the extremely delicate elastic fibrils, which are to be seen around the cells near the margin of the turnour, have the appearance of having been laid down by the cells around them. No such delicate fibrils occur in normal conditions, nor do the thinnest elastic fibres to be found in healthy tissues ever show the peculiar arrangement of these fibrils around the cells. It is difficult to see how these fibrils could have reached their position if they were not a new formation.

The most interesting question is, How are the new elastic fibres formed? Are they offehoots of pre-existing fibres? Do the cells become transformed into the fibres? Or are the fibres laid down around the cells?

The existence of new elastic fibres in places where they not only do not appear to have any connection with pre-existing fibres, but where there are no pre-existing fibres to be seen, points against the first. On the other hand, it must be remembered that new elastic fibres are formed near the internal elastic lamina of the arteries, and that occasionally, but not often, small sheaves of new elastic fibres are connected by branches with the elastic fibres in the walls of the vessels. Against this must be placed the fact that in sarcoma most of the vessels possess no elastic tissue in their walls, and yet quite as great a new formation of elastic fibres takes place in the sarcoma as in carcinoma of the testis. Fischer, however, says that the largest amount of new elastic tissue is formed in tumours of those organs which are normally rich in elastic fibres, but this does nothing more than suggest the possibility of there being some connection between the amount of elastic tissue in an organ and in neoplasms of that organ. What the connection is must be determined in other ways.

I have seen no evidence of the transformation of cells into elastic fibres. On the other hand, the extremely delicate fibrils already described, their arrangement around the cells, their occurrence in the most richly cellular parts of the growth, the fact that the amount of new elastic tissue is greatest in those neoplasms which are richest in cells, all seem to indicate that the new elastic fibres are laid down around the cells, one might almost say are secreted by the cells.

A further fact in support of this view is that sometimes the very 
delicate elastic fibres have a beaded appearance, the beads being united by very fine strands, and sometimes the fibrils are represented by a row of beads which, though close together, are not, so far as one could see, connected in any way. Hamilton's researches support this view, and so does Jores's observation that new elastic fibres are more common in maliguant growths than in connective tissue tumours.

\section{Sarcoma of the Testis.}

Sarcoma rapidly and extensively destroys elastic tissue. As a rule, there is no trace of any normal elastic fibre in the body of the growth. At the edge of the growth, where the normal tissues are being infiltrated, the elastic fibres of the sheath of those seminal tubules which are being invaded are being separated from one another by the cells of the tumour. This separation may be so great that the elastic fibres sometimes stand out at right angles to the wall of the seminal tubule.

Sometimes only one side of a seminal tubule is being attacked, and whilst on this side the epithelium is being destroyed, and the elastic fibres separated, broken up and removed, on the other side they are unaffected. Though the elastic fibres are broken up, yet the fragments are not so small as those seen in tuberculosis, nor do the broken ends taper away to long slender points.

As in other conditions, so also in sarcoma, the elastic tissue seems comparatively resistant, and the growth often advances round the seminal tubules without at first invading them. Not infrequently, however, the elastic fibres in the sheath of these tubules are swollen and do not stain well, and in extreme cases the elastic sheath seems to lose its fibrillar structure and take on a homogeneous appearance.

In other cases the elastic fibres have completely disappeared, and all that remains of the seminal tubules are masses of epithelium squeezed together by the growth.

The process by which the elastic sheath of the seminal tubules is in many cases destroyed consists of the passage of the sarcoma cells through the meshes of the network of elastic fibres, which are then forced apart and broken.

The vessels in sarcoma consist chiefly of large capillaries without any elastic tissue in their walls.

Sarcomata of the testis very often contain a quantity of new elastic fibres resembling those seen in carcinomata. The description of these fibres in carcinoma applies to those in sarcoma with very slight differences. The very delicate fibrils are beautifully seen in sarcoma (Plate XXXII. Fig. 11), and an intermediate stage between the large masses and the delicate fibrils often occurs in sarcoma, though it may also sometimes be found in carcinoma. This stage consists of small bundles, sheaves, or ribbons of new elastic fibres, which are of moderate 
size, and are not at all closely interwoven. Though there are several cells amongst these fibres, yet the cells are not nearly so numerous (Plate XXXII. Fig. 12) as in the parts where the very delicate fibrils occur, nor so scanty as in the large masses of thick fibres.

Sometimes the ribbons these fibres form are of great length, and stretch right across the section. The small sheaves consist of from half a dozen to a dozen short fibres clustered together.

\section{Cystic Adenoma of the Testis.}

In this condition there is much less elastic tissue present than in the normal organ. To a great extent this is due to the fact that the number of seminal tubules is much smaller than usual, their place being taken by the adenomatous tissue, which consists mainly of large cystic spaces lined by columnar or cubical epithelium, but also to the fact that the sheaths of those seminal tubules present are thinner than normal and contain fewer elastic fibres. There was no evidence of any active destruction of elastic tissue.

\section{Ngana.}

I obtained some testes from rats which died after inoculation with trypanosoma for experimental purposes. The elastic tissue was in no way affected.

\section{Destruction of Elastic Tissue.}

Several points in connection with this subject have already been mentioned, but it may be useful to shortly draw attention to them again.

Destruction of elastic fibres was observed by Miller (1905) in emphysema, gangrene, septic infaret, tuberculosis, and sarcoma, but not in lobar pneumonia ; by Melnikow-Raswedenkow (1899) in tuberculosis and sarcoma; by Wechsberg (1901) in from six to twenty-four hours after intra-venous injection of tubercle bacilli ; by Watanabe (1902) within twenty-four hours after experimental inhalation of tubercle bacilli. Sawada (1902) says that the tubercle bacillus destroys elastic fibres more rapidly than any other organism except the pyogenic cocci. Eijkman (1904) says that the enzymes of the Barillus anthracis and $B$. pyocyaneus dissolve elastic fibres. Federmann (1901) mentions two main factors as causing the destruction of the elastic fibres in tuberculosis of the testis, namely, neechanical distension of the seminal tubules and a poison formed by the tubercle bacillus; but he also evidently thinks that the tuberculous granulation tissue plays an important part. Rona (1900) mentions a theory that the giant cells in tuberculosis destroy the elastic fibres by a kind of phagocytic process. Herxheimer (1903) argues that since destruction of elastic tissue in tuberculosis may take place before any granulation tissue has formed, the destruction of the elastic fibres ought not to be ascribed to the granulation tissue; and since the greatest amount of destruction is to be found in the vicinity of those places where most tubercle bacilli are present, it must be due to some substance formed by the bacilli. Unna thinks that in tuberculosis the endothelioid cells destroy the elastic fibres. 
I have seen no evidence of any action on the part of the giant cells resembling that described by Rona. Neither can I see any reason for believing that mechanical distension of the seminal tubules plays an important part in the destruction of elastic tissue. So far from showing signs of intra-tubular pressure, the fibres of the elastic sheath are separated from one another by small round cells, even when the tubules are full of tuberculous granulation tissue.

Having said that no signs of pressure within the tubules are to be seen, it is almost superfluous to add reasons why such a condition, even if it did exist, has no important action in destroying elastic fibres; but it may be useful to remember that the elastic tissue is rapidly destroyed in tuberculosis of other organs which contain no tubules to he distended; that the elastic sheath of seminal tubules which are becoming involved in a large tuberculous nodule, on the edge of which they lie, are destroyed as rapidly and as thoroughly as in other cases. This is also the case with tubules which contain no tuberculous inaterial.

The work of Wechsberg, Watanabe, and Herxheimer is strong evidence in support of the view that the tubercle bacillus does produce a substance which dissolves the elastic fibres. This is strenghtened by the broken fibres in tuberculosis whose ends taper away to long fine points as though they were being dissolved and not eaten away. These form a strong contrast to the thickened, curled up, and club-shaped ends of the broken fibres in the walls of the arteries in arterio-sclerosis. Again, small submiliary tubercles are often surrounded by an area clear of elastic tissue beyond the reach of the small round cells.

Still, two of the chief changes in tuberculosis are the separation of the elastic fibres from one another by an infiltration of small round cells and the breaking up of the fibres into shorter pieces. The small round cells not only separate the fibres, but they may also be seen in large numbers closely applied to the ends and sides of the broken. fibres, aud sometimes flattened out along them as though they were playing some part in their destruction.

It is possible that there are two factors at work, the poison formed by the tubercle bacilli and the small round cells of the granulation tissue. When the bacilli are virulent, and the resistance of the tissues weak, the greater part of the destruction may be the work of the poison formed by the bacilli, whilst the small round cells only complete the process. On the other hand, when the resistance of the tissues is great and the bacilli are not very virulent the process of destruction is less acute, and the granulation tissue does the larger part of the work.

The statement that in syphilis and carcinoma the elastic tissue is not destroyed is only relatively and not absolutely true. Compared with tuberculosis, carcinoma destroys the elastic fibres only slightly 
and slowly; and compared with carcinoma, syphilis causes very little or almost no destruction of elastic tissue; but in both these conditions destruction does occur, though in tertiary syphilis it is probably the result of nutritional changes. Consequently one can make a list of pathological conditions, placing the members of it in order according to the amount of destruction of elastic tissue they cause. In such a list suppurative processes which cause most destruction would come first, and such diseases as lobar pneumonia last, whilst tuberculosis, sarcoma, carcinoma, and gumma would be intermediate members.

It is not easy to say how the elastic tissue is destroyed in sarcoma. There is no evidence that the cells of the growth form any substance which dissolves the fibres. It may be that they destroy the elastic fibres by a kind of phagocytic action, but it is impossible to make any definite statement on this point.

I owe a debt of gratitude to several friends for their kind help. Dr. A. E. Boycott, Mr. R. F. Moore, and Mr. Clayton Green gave me valuable specimens. Dr. James Miller was good enough to allow me to read the proof of his article on the elastic tissue of the lung. My thanks are also due to Professor Baumgarten of Tiibingen, to Dr. Peter Rona of Berlin, to Mr. T. S. P. Strangeways of Cambridge, but above all to Professor Sims Woodhead for much help and advice. This work was originally done for an M.D. thesis in the University pathological laboratory at Cambridge, and owes not only its inception but its completion to Professor Woodhead.

\section{REFERENCES.}

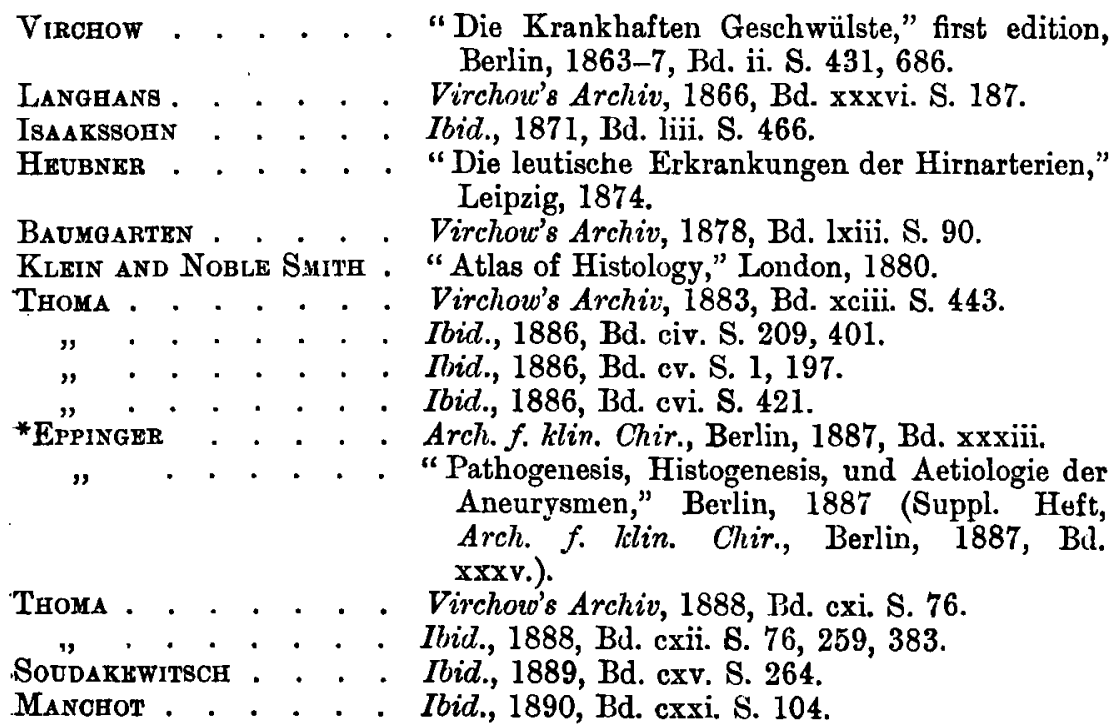


De Rochemont . . . . Arch. f. Dermat. u. Syph., Wien, 1893, S. 565.

*Goldmax . . . . . . Beitr. z. klin. Chir., Tübingen, 1893.

Riehl Und Gutrentag . Arch. f. Dermat. u. Syph., Wien, 1894, Bd. xxvii. S. 175.

Hohenemser - . . . Virchow's Archiv, 1895, Bd. cxl. S. 192.

Hutchinson . . . . . "Atlas of Pathology:" New. Syd. Soc., 1895, Fasc. 10.

*Drtrel . . . . . . Wien. klin. Rundschau, 1896, Nos. 26 and 2T. •

Meissner . . . . . . Deutsche med. Wchnschr., Leipzig, 1896, VereinsBeilage, S. 56.

Dmitrijerf . . . . . Beitr. \%. path. Anat. u. z. allg. Path., Jena, 1897, Bd. xxii. S. 207.

Czyhlarz u. Helbing . . Centralbl. f. allg. Path. u. path. Anat., Jena, 1897, Bd. viii. S. 849.

Conts AND AULD . . . Journ. Path. and Bacteriol., Edin. and London, 1897, vol. iv. p. 78 .

Jones . . . . . . . Beitr. z. path. Anat. u. z. allg. Path., Jena, 1898, Bd. xxiv. S. 455.

Weigert . . . . . . Centralbl. f. allg. Path. u. path. Anat., Jena, 1898, Bd. ix. S. 289.

Kanthack and Pigg . . Journ. Path. and Bacteriol., Edin. and London, 1898, vol. v. p. 78.

Lewinsberg . . . . "Beiträge zur Kenntniss der elastischen Gewebes," Zürich, 1898.

Sudsurr . . . . . . Virchow's Archivi, 1899, Bd. clvii. S. 438.

MalkofF . . . . . . Beitr. z. path. Anat. u. z. allg. Path., Jena, 1899, Bd. xxv. S. 431.

Abramow . . . . . . Ibid., 1899, Bd. xxvi. S. 202.

MELNIKow-RASWEdEN Kow . Ibid., 1899, Bd. xxvi. S. 54.6.

Bends . . . . . . Centralbl. f. allg. Path. u. path. Anat., Jena, 1899 , Bd. x. S. 832.

ZIEGLER . . . . . . Mid., 1899, Bd. x. S. 832.

Hansmane . . . . . Mrid., 1899, Bd. x. S. 833.

OrTH . . . . . . . Ibid., 1899, Bd. x. S. 833.

SchmoR1. . . . . . Ibid., 1899, Bd. x. S. 833.

RuNa . . . . . . . Beitr. z. path. Anat. u. z. allg. Path., Jena, 1900, Bd. xxvii. S. 349.

Jones . . . . . . . Ibid., 1900, Bd. xxvii. S. 381.

Woltk: . . . . . . Ibid., 1900, Bd. xxvii. S. 575.

Obermuller . . . . . Ibid., 1900, Bd. xxvii. S. 586.

* Batmgarter . . . . Wien. med. Welnschr., 1900, No. 44, S. 2058.

* " $\quad$. . . . . Ibid., 1900, No. 47, S. 2210.

* Kraemer . . . . . Ibid., 1900, No. 45, S. 2122.

PICk . . . . . . Samml. klin. Vortr., Leipzig, 1900, No. 283.

*ORTн . . . . . . . Verhandl. d. deutsch. path. Gesellsch., Berlin, 1900.

Williasis . . . . "Contributions to the Science of Medicine, dedicated by his pupils to W. H. Welch," Baltimore, 1900, p. 291.

White. . . . . . . Johns Hopkins Hosp. Bull., Baltimore, 1900, vol. ii. p. 185.

Fedramany . . . . . Virchow's Archiv, 1901, Bd. clxv. S. 469.

Wechsberg . . . . . Beitr. z. path. Anat. u. z. allg. Path., Jena, 1901, Bd. xxix. S. 203.

${ }^{*}$ Gröf . . . . . . München. med. Wchnschr., 1901, No. 40, S. 1555.

*Micharis . . . . . Deutsche med. Wehnschr., Leiprig, 1901, S. 219. 


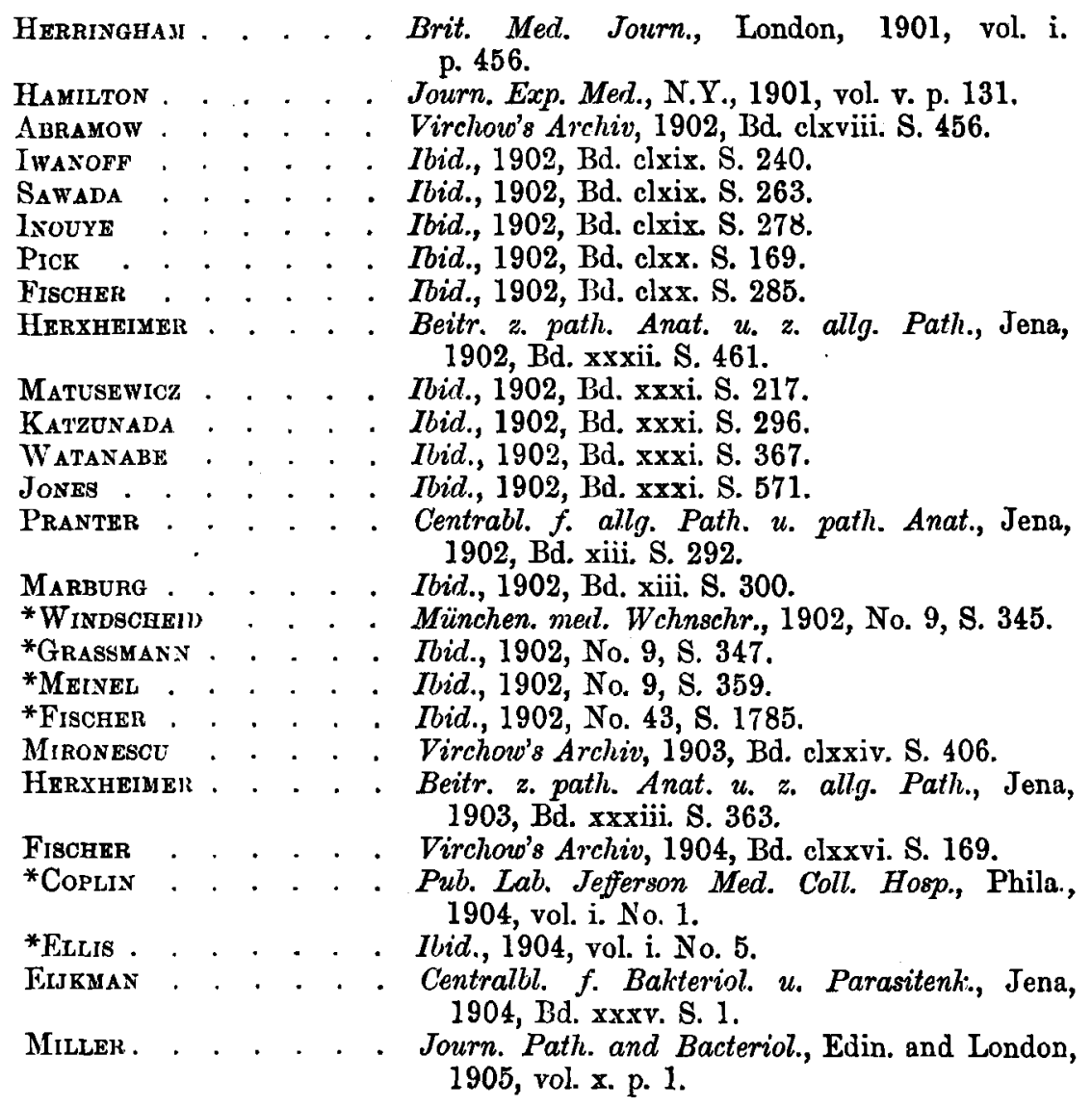

\section{DESCRIPTION OF PLATES XXXI. AND XXXII.}

\section{Plate XXXI.}

Fig. 1.-Tuberculosis of the testis. Tubercle in the interstitial tissue outside the seminal tubule. $(\times 400$.

Fig. 2.-Tuberculosis of testis. Tubercle in interstitial tissue near small vessel outside the seminal tubule. $(x 400$.)

Fia. 3. Gumma of testis. Increase in the amount of intertubular tissue. $(\times 200$.)

Fra. 4.-Carcinoma testis. New elastic fibres. $(\times 400$.

Fra. 5.-Carcinoura testis. New elastin fibres. $(\times 400$.

Fr(. 6.-Epithelioma of testis. Large amount of new elastic tissue. $(\times 4$.

\section{Plate XXXII.}

Fig. 7.-Tuberculosis of the testis. Destruction of the elastic tiesue by a large tuberculous nodule. The epithelium of the seminal tubules is in some cases entirely destroyed. Giant cell. Small vessel. Remains of the elastic sheath of seminal tubules. $(\times 40$.) 
Fic. 8.-Tuberculosis of the testis. Tubercle starting in the tiny layer of the areolar tissue between the epithelium and the elastic sheath of the seminal tubule, separating and destroying the sheath and the epithelium, but not yet having perforated either. ( $x$ 700.)

Fig. 9.-Tuberculosis of the testis. Tubercle starting in the meshes of the elastic sheath of the seminal tubule. Elastic fibres separated and destroyed. Epithelium unaffected. $(x$ 700.)

FIG. 10.-Epithelioma of the testis. New formation of elastic fibres.

FIG. 11.-Sarcoma of the testis. New formation of elastic fibres. Very delicate fibrils surrounding the cells. Rows of granules of elastic material round the cells. $(\times 700$.

Fig. 12. Sarcoma of the testis. New formation of elastic fibres, $(\times 700$. 